\title{
MAKALAH \\ KASUS KORUPSI DIRUT PLN SOFYAN BASIR
}

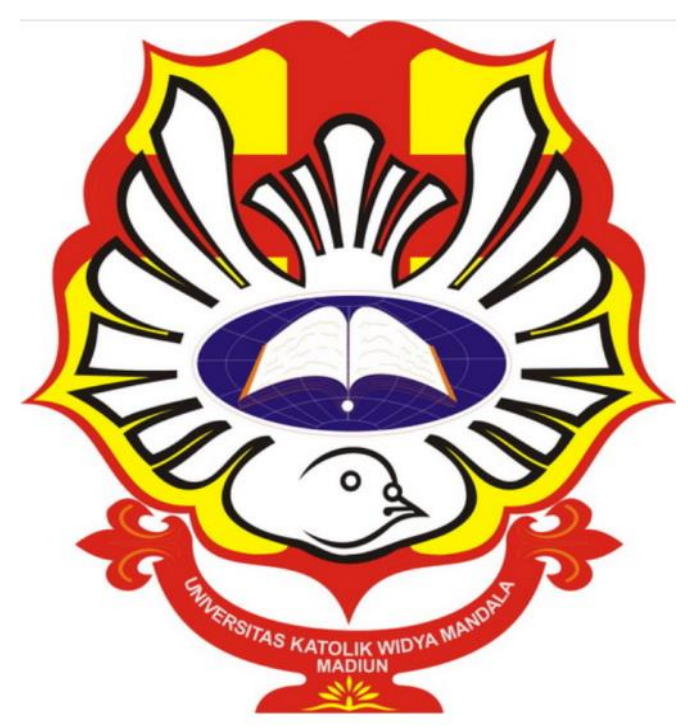

DISUSUN OLEH :

NAMA : SITI NUR FATIMAH

NIM : 32318018

\section{PROGRAM STUDI D-III FARMASI}

FAKULTAS MATEMATIKA DAN ILMU PENGETAHUAN ALAM

UNIVERSITAS KATOLIK WIDYA MANDALA MADIUN 


\begin{abstract}
Abstrak
Pada bulan April 2019, KPK menetapkan dirut PLN Sofyan Basir sebagai tersangka kasus suap atas pembangunan PLTU Riau-1 di provinsi Riau. korupsi sendiri berarti penyalahgunaan jabatan yang digunakan untuk kepentingan pribadinya. Kasus Sofyan Basir dipandang dari sudut pandang etika tidak dapat dikatakan sebagai "tindakan manusia" dikarenakan tidak memenuhi standar atau kriteria tertentu yang bersifat normatif. sedangkan berdasarkan sudut pandnag actus humanus, Sofyan Basir memenuhi semua ke tiga kriteria yakni antara lain mau, tahu, dan bebas untuk melakukan tindakan korupsi tersebut dengan tanpa paksaan dan memiliki pengetahuan bahwa korupsi sangat merugikan bagi negara. maka dari itu pertanggung jawaban sepenuhnya diberikan kepada subjek atau pelaku atas tindakannya yakni Sofyan Basir.
\end{abstract}

\title{
Keywords
}

Korupsi, Etika, Hukuman 
Setelah diperiksa di gedung kpk di Jakarta, direktur PLN yakni Sofyan Basir ditetapkan oleh kpk sebagai tersangka dalam kasus korupsi. Sofyan Basir sebagai direktur PLN ini ditetapkan sebagai tersangka berdasarkan hasil yang merupakan pengembangan kasus dugaan suap yang terkait dengan kerja sama pembangunan PLTU Riau-1 di provinsi Riau.

Sofyan Basir bersama teman - temannya diduga membantu Eni dkk menerima hadiah/ janji dari Kotjo untuk kepentingan proyek Independent Power Producer (IPP) Pembangkit Tenaga Uap Mulut Tambang (PLTU) di Riau-1.

Berdasarkan hasil siding KPK dinyatakan bahwa Sofyan Basir telah melanggar pasal 12 huruf a atau pasal 12 hurut b atau pasal 11 Undang-undang Nomor 31 Tahun 1999 tentang Pemberantasan Tindak Pidana Korupsi sebagaimana diubah dengan Undang-undang Nomor 20 Tahun 2001 jo Pasal 55 ayat (1) ke-1 KUHP atau Pasal 56 ayat (2) KUHP jo Pasal 64 ayat (1) KUHP tentang pemberantasan tindak pidana korupsi sebagaimana dimmjhuj dengan UU no. 20 tahun 2001. Berikut ini kronologi bagaimana Dirut PLN Sofyan Basir menjadi tersangksa KPK.

Seperti yang dikatakan sebeumnya Direktur Utama PLN ditetapkan sebagai tersangka oleh KPK terkait dengan kerja sama pembangunan PLTU Riau-1 di Provinsi Riau. Sebelum kasus suap yang di lakukan oleh Sofyan Basir ini, KPK terlebih dahulu telah melakukan Operasi Tangkap Tangan (OTT) terhadap Wakil Ketua Komisi VII DPR Eni Maulani Saragih saat menerima suap dari pemilik saham Blackgold Natural Resources Ltd Johannes Budisutrisno Kotjo.

Diduga penerimaan suap yang diterima oleh Eni Maulani Saragih ini merupakan hasil penunjukkan langsung Sofyan Basir kepada perusahaan Johannes Kotjo supaya memberikan suap kepada Eni Maulani Saragih sebagai Ketua Komisi VII DPR ini untuk menggarap proyek pembangkt listrik tersebut. Sebelum benar-benar menyandang status tersangka kasus ini, Sofyan Basir sudah berulang kali dipanggil untuk diperiksa oleh KPK. Namun lebih dari 3 kali pertemuan Sofyan Basir oleh KPK ini hanya mengatakan bahwa dia, Sofyan Basir hanya diperiksa untuk saksi atas Kotjo.

Namun seiring berjalannya kasus tersebut,, Sofyan Basir diketahui sudah sembilan kali mengikuti dalam pertemuan antara Eni Saragih dan Johannes Kotjo., ditemani oleh Direktur Pengadaan Strategis 2 PT PLN Persero Supangkat Iwan Santoso. Akhirnya pada 
tanggal 23 April 2019, Sofyan Basir resmi ditetapkan sebagai tersangka setelah sebelumnya hanya sebagai saksi atas Kotjo.

Kita semua pasti tahu bahwa tindakan korupsi sudah tidak sedikit bahkan sudah mendarah daging terjadi di Indonesia. Dengan maraknya kasus korupsi di Indonesia pemerintah bergotong-gotong membentuk suatu badan yang disebut Komisi Pemberantas Korupsi ayau yang lebih dikenal dengan KPK ini, dengan tugas utamanya khusus untuk memberantas semua tidak korupsi yang terjadi di Indonesia.

Sebagaimana kita tahu pengertian korupsi sendiri adalah suatu tindakan tidak manusiawi dengan menyalah gunakan jabatan atau wewenang yang tentukan dilakukan oleh seorang pejabat demi mendapatkan keuntungan pribadi.

Yang berdasarkan kasus diatas diketahui Spfyan Basir sebagai Direktur Utaman PLN melakukan kasus suap dan diduga ia mendapatkan keuntungan yang tidak sedikit, keuntungan yang dia dapatkan merugikan sebagian bahkan semua karyawan PLN dan dapat mempengaruhi pemerataan pembangunan listrik untuk bangsa Indonesia.

Jadi seharusnya tindakan suap yang dilakukan Sofyan Basir ini tidak kita contoh, dan bahkan tidak bias dibiarkan berlalu begitu saja dengan tanpa tindakan yang tegas. Beruntungnya KPK mampu mengungkap kasus yang dilakukan oleh Sofyan Basir yang sekarang telah menjadi mantan Dirut PLN itu. Tidak hanya kehilangan jabatannya, Sofyan Basir dipastikan mendapatkan sanksi hukuman atas tindakannya yang melanggar UU itu.

Sebagaimana kita tahu tindakan korupsi ini merupakan tindakan yang tidak bermoral. Dimana pengertian "bermoral" sendiri dapat diartikan suatu tindakan yang dilakukan oleh manusia itu sendiri sehingga mereka dapat disebut manusia atas tindakan yang ia lakukan sendiri.

Jelas sekali tindakan suap yang dilakukan Sofyan Basir tersebut tidak dapat dapat disebut tindakan yang bermoral atau kata lain memiliki etika. Karena tindakan korupsi sangat tidak memiliki nilai etis untuk dilakukan oleh manusia bahkan dalam kerangka manusiawi. Sudah jelas sekali tindakan korupsi ini tidak memiliki suatu nilai manusiawi yang artinya tidak memiliki manfaat bagi tindakan etika yang menjunjung tinggi menuju atau mengarah kepada kebaikan ini. 
Karena memang kasus korupsi sudah dipastikan akan dan selalu mengarah pada keburukan. Bagimaimana tidak, tindakan korupsi yang dilakukan oleh mantan Dirut PLN, Sofyan Basir ini mengakktkan banyak kerugian yang dialami banyak pihak mulai dari karyawan, perusahaan, bahkan Negara pun mendapatkan dampak buruk atas tindakan tidak beretika tersebut. Kita bayangkan saja apabila dana yang Sofyan Basir korupsi tersebut tentu saja dapat untuk pemerataan pembangunan listrik untuk daerah Indonesia yang belum terjamah listrik.

Tindakan korupsi Sofyan Basir ini menurut saya tidak dapat dikatan sebagai "tindakan manusia", mengapa demikian? Karena tindakan manusia sendiri mempunyai penegrtian sebagai tindakan yang dilakukan oleh manusia yang memiliki atau memenuhi standar atau kriteria normatif tertentu. Dimana pengertian dari normatit sendiri adalah tindakan yang tidak hanya memuja pada ilmiah tetapi justru mengedepankan pada normanorma yang ada. Yang juga dapat diartikan tindakan berdasarkan akal budi manusia yang sehat dan benar.

Normatif sendri tidak dapat dikatakan sebagai norma-norma agama tertentu (agama Islam, Hindu, Budha, dan sejenisnya, normatif juga tidak bias dikatakan sebagai tradisi atau budaya yang ada dalam masyarakat yag kita tinggali. Karena pada dasarnya normatif sendiri adalah sesuatu yang sistematis atau sesuai dengan nilai hidup manusia yakni nilai yang berasal dari akal budi manusia.

Dari penjelasan normatif tersebut, kita pasti tahu bahwa tindakan korupsi yang dilakukan oleh mantan Dirut PLN, Sofyan Basir jelas tidak bersumber dari akal budi manusia karena jika Sofyan Basir melakukan tindakan yang bersumber dari akal budi manusia atau kata lain normatif, Sofyan Basir akan enggan menyuruh Kotjo untuk memberi hadiah kepada Eni untuk pembangunan proyek PLTU Riau-1.

Jika tindakan manusia sudah jelas tidak memiliki normatif yang merupakan suatu unsur yang harus ada pada suatu tindakan manusia, sudah dapat dikatakan bahwa tindakan yang dilakukan Sofyan Basir tersebut bukanlah tindakan manusia.

Manusia tidak akan pernah melakukan tindakan yang sangat keji dan sangat merugikan semua pihak tersebut. Maka tdak heran jika para koruptor di Negeri ini disebut sebagai "tikus Negara" yang artinya sama seperti pengertian korupsi tadi yakni mengambi keuntungan sebanyak banyaknya untuk kepentingan dirina sendiri. 
Daalam tindakan manusia sendiri dapat dibedakan menjadi dua yaitu action of human being (actus hominis) dan human action (actus humanus). Actus hominis sendiri berarti semua tindakan yang dilakukan manusia bahkan semua mahkluk hidup seperti makan, tidur, minum, dan sejenisnya.

Namun kali ini saya akan membahas bagaimana kasus korupsi Sofyan Basir dalam sudut pandang actus humanus atau human action. Actus humanus sendiri memiliki pengertian setiap perbuatan yang memiliki moral, artinya etika harus ada saat seseorang bertndak agar tikatan sebagai actus humanus.

Actus humanus sendiri memiliki 3 unsur atau syarat pokok antara lain mau, tahu, dan bebas. Kita akan bahas yang pertama, dimana "mau" berarti seseorang dalam melakukan suatu tindakan berdasarkan kebebas mereka sendiri yag artinya tanpa ada pemaksaan dari pihak lain. Dapat diterapkan dalam kasus Sofyan Basir diatas, jelas dia tidak mendapat tekanan atau pemaksaan dari pihak manapun untuk melakukan tindakan suap itu karena semata-mata hanya untuk kepentingannya sendiri.

Yang kedua adalah "tahu" yang artinya sebelum manusia bertindak mereka harus memiliki suatu pengetahuan terlebih dahulu atas apa yang akan dilakukannya, maksudnya di sini mereka tahu apakah tindakan yang akan mereka lakukan apakah sudah mengarah kebaikan atau belum. Seperti kasus Sofyan Basir diatas jelas sekali dia sudah cukup pintar untuk mengetahui bahwa tndakan suap adalah suatu tindakan yang mengarah kepada keburukan.

Dan yang terakhir ada "bebas". Karena pada dasarkan actus humanus sudah berdasar pada tindakan yang bebas, artinya tindakan yang menjadikan manusia yang melakukan tidakan itu sendiri sebagai subjek tindakan atau dapat dikatakan sebagai seseorang yang bersangkutan dalam tindakan yang ia lakukan dan atas apa segala tindakannya, dia harus bertanggung jawab atas konsekuensi yang mungkin ada akibat tindakannya.

Dapat kita simpulkan dari sudut pandang actus humanus ini kasus korupsi Sofyan Basir. Sudah selayaknya ia mendapatkan sanski atas tindakan tersebut karena dalam ia bertindak, Sofyan Basir sangat jelas ia tahu, mau, dan bebas dalam bertindak menuju keburukan. Ia juga sebagai subjek dalam tindakannya dan harus mempertanggung jawabkan atas konsekuensi atas tindakan korupsimya. 
Berkaitan dengan tindakan / kehendak bebas ini, Thomas Aquinas mengklarifikasikan menjadi dua macam, yakni directly voluntary dan indirectly voluntary. Directly voluntary dimaksud dari apa yang langsung dikehendaki atas keputusan perbuatannya. Sedangkan indirectly voluntary dapat dikatakan sebagai konsekuensi dari tindakan yang diperbuatnya, dkatakan kosekuensi karena biasanya dlam suatu tindakan, indirectly voluntary bertindak sebagai suatu hal atau akibat yang tidak dikeendaki dan seperti halnya akibat biasanya indirectly voluntary lebih mengarah kepada keburukan.

Oleh karena direct voluntary harus segala tindakan yang mengarah kepada kebaikan. Karena segala tindaka yang menjunjung kepada kebaikan harus diutamakan dan sangat tidak boleh menjadi indirectly voluntary.

Dalam kasus suap yang dilakukan oleh Sofyan Basir ini, ia melakukan tindakan yang mengarah kepada keburukan tetapi keburukan dari tindakannya dilakukan secara direct voluntary. Kasus Sofyan Basir ini merupakan contoh cara seseorang untuk mendapatkan kebahagiaan atau harta dan sejenisnya dengan memperjuangkan segala cara-cara yang tidak baik. Seharusnya jika ia ingin mendapatkan apa yang ia inginkan harus memperjuangkannya dengan cara-cara atau jalan yang baik, seperti bekerja dengan tekun contohnya dan bukan malah akan melakukan tindakan korupsi yang sanngat salah ini.

Bahkan korupsi yang dilakukan oleh Sofyan Basir yang merupakan tindakan direct voluntary itu, memiliki kosekuensinya atau kita menyebutnya indirectlu voluntary. Dalam konteks indirectly voluntary ini "Sofyan Basir" merupakan satu - satunya pihak atau subjek yang harus mempertanggung jawabkan tindakan yang ia kehendaki.

Namun yang membedakan disini adalah intensitas tanggung jawab si pelaku atas tindakannya yang menyangkut direct voluntary. Maksudnya apabila indirectly voluntary atau konsekuensi dari tindakannya tidak dikehendaki makan tidak semua tanggung jawab penuh diberikan kepada pelaku atau subjek karena ia tidak menghendaki konsekuensinya itu sepenuhnya.

Beda lagi dengan tindakan suap yang dilakukan oleh Sofyan Basir ini, karena ia sepenuhnya adalah pelaku yang menghendaki atau yang mengambil keputusan atas tindakannya. Maksudnya disini Sofyan Basir jelas menghendaki tindakan suap yang ia lakukan demi kepentingan pribadi tercapai. Jadi dalam kasus ini Sofyan Basir bertanggung 
jawab penuh atas tindakannya dan intesitasnya mungkin sangat besar jika dibandingkan pada kasus yang konsekuensinya tidak pelaku kehendaki.

Hukum obyektif adalah hokum yang hanya berlaku secara umum di suatu Negara dan tidak mengenal orang atau golongan tertentu, maksudnya hokum yang berlaku bagi seurus masyarakat dalam suatu Negara. Sedangkan hukum subjektif adalah hokum yang timbul dari hukum objektif, hukum subjektif biasanya timbul karena adanya hukun objektif. Hukum subjektif juga dapat dikatakan hukum yang berasal dari dalam diri si pelaku sendiri.

Sebagai contohnya kasus korupsi Soofyan Basir ini, hukum objektif dalam kasus tersebut adalah Sofyan Basir mendapattkan hukuman penjara selama ketentuan yang berlaku yang sesuai dengan pelanggaran yang dilakukannya. Sedangkan hukum subjektif dari kasus tersebut adalah Sofyan Basir mungkin akan merasa bersalah dalam hidupnya karena tindakan yang ia lakukan.

Maksudnya disini, mungkin seseorang akan bebas atau dapat lepas dari hukuman yang berlaku di suatu Negara atau disebut hukum objektif, tetapi ingat aka nada hukum subjektif yang akan menghantui si pelaku selama hidupnya. Karena pada dasarnya hukum subjektif berasal dari dalam hati nurani manusia yang bersifat kekal atau abadi.

Hati nuraini pun diklasifikasikan menjadi lima macam antara lain ada hati nurai sesat, hati nurani tumpul, hati nurani bimbang, hati nurani tajam, hati nurani skrupel. Menurut saya Sofyan Basir masuk kedalam hati nurani dengan klasifikasi sesat.

Pengertian dari hati nurani sendiri adalah kapasitas yang dimiliki seseorang utuk dapat membedakan mana yang baik dan buruk. Sedangkan hati nurani sesat adalah dimana seseorang tidak bisa lagi membedakan mana yang baik dan mana yang buruk. Dengan kata lain mereka yang memiliki hati nurani sesat biasanya kebaikan dan keburukan akan terbalik.

Namun hati nurai yang sesat dapat dikembalikan kepada hati nurani yang tajam, yang mampu dengan cepat membedakan mana yang baik dan buruk sehingga ia dapat menegetahui bahwa sesungguhan tindakan yang ia lakukan tidak semestinya atau sewajarnya. Dengan cara mendekatkan diri dengan Tuhan dan dapat pula melakukan kegiatan - kegiatan yang positif. 


\section{DAFTAR PUSTAKA}

Dewantara, A. (2017). Filsafat Moral (Pergumulan Etis Keseharian Hidup Manusia).

Dewantara, A. (2017). Diskursus Filsafat Pancasila Dewasa Ini.

https://m.liputan6.com/news/read/3989797/kpk-segera-beberkan-peran-sofyan-basir-dalam-suappltu-riau-1

https://nasional.kompas.com/read/2019/04/23/17165241/kpk-tetapkan-dirut-pln-sofyan-basirtersangka-korupsi-pltu-riau-1

https://www.liputan6.com/bisnis/read/3949012/kronologi-dirut-pln-sofyan-basir-jadi-tersangka-kpk https://sosialhukum.blogspot.com/2016/01/hukum-objektif-dan-hukum-subjektif.html?m=1 